\title{
KAJIAN SOSIAL EKONOMI SID PANTAI CALANG DAN PANTAI KRUENG SABEE, KOTA ACEH JAYA
}

\author{
Sumarna Hasan *)
}

\begin{abstract}
Town Calang besides area setlement location also as Calang municipal administration center with various activity of economics society. Around this area there are also fishery activity and fishpond as Coastal area fisherman society living of Calang. Effect of existence of Tsunami and earthquake have resulted changing coastal morphology where so that have resulted the resignment of coastline as far as $\pm 100-200 \mathrm{~m}$. Besides have eliminated coastal area, tsunami have also eliminated some of joint streets pass by quickly Banda Aceh - Meulaboh which have location around this coast..
\end{abstract}

Coastal protection of Calang And Krueng Sabee besides conducted with coastal building development, is also planned by coastal protection brand involved. Coastal protection involved represent belt green with Coconut crop cultivation and Mangrove. Coastal Protection made in which suited for applied at this study location is breakwater building. Result of calculation from economic analysis, this development within 25 year at interest rate $24 \%$ estimated to have NPV equal to $1.018 .582 .359,72$, Net B/C 1,131 and IRR is $26,89 \%$.

Key Words : Coastal Protection, Economy Analiysis, Calang City 


\section{PENDAHULUAN}

Provinsi Nangroe Acch Darussalam merupakan Provinsi ujung barat Pulau Sumatera dan merupakan wilayah yang rusak parah akibat bencana alam Gempa dan Tsunami, Bencana Alam (Disaster) Gempa Bumi dan Gelombang Tsunami yang menimpa Provinsi Nangroe Aceh Darussalam (NAD) pada tanggal 26 Desember 2004 telah menyebabkan kerusakan pantai termasuk Prasarana dan Sarana permukiman penduduk baik di perkotaan maupun pedesaan khususnya pada wilayah perairan bagian pantai, bencana alam ini juga mengakibatkan hilangnya kawasan pantai yang ada di Nangroe Aceh Darussalam khususnya pada kawasan pantai Kota Calang Kecamatan Krueng Sabee Kabupaten Aceh Jaya.

Pantai KotaCalang terletak $\pm 1.5 \mathrm{~km}$ dari pusat kecamatan Krueng Sabee. Selain kawasan permukiman lokasi ini juga sebagai pusat pemerintahan Kota Calang dengan berbagai aktifitas kegiatan perekonomian masyarakat. Di sekitar kawasan ini terdapat pula aktifitas perikanan dan tambak sebagai mata pencaharian masyarakat nelayan kawasan Pantai Calang. Akibat adanya gempa dan Tsunami telah mengakibatkan berubahnya morfologi pantai dimana telah terjadi abrasi pantai yang sangat besar sehingga telah mengakibatkan mundurnya garis pantai sejauh $+100-200 \mathrm{~m}$. Selain telah menghilangkan kawasan pantai, tsunami juga telah menghilangkan sebagian ruas jalan lintas Banda Aceh - Meulaboh yang berlokasi di sekitar pantai ini.

Untuk menindak lanjuti persoalan serta hal-hal tersebut diatas diperlukan upaya-upaya penanggulangan. Penanggulangan abrasi maupun erosi pantai secara terpadu dan menyeluruh dangan melakukan Survei Invesigasi dan Desain secara rinci terhadap terjadinya fenomena alam tersebut. Kajian sosial ekonomi merupakan salah satu kajian SID untuk mendapatkan hasil perencanaan yang baik sehingga dapat berhasil tepat guna ekonomis dan efisien.

\section{METODE}

$\sqrt{ }$ Kegiatan survei sosio agro ekonomi meliputi pelaksanaan pengumpulan data sekunder sosio agro ekonomi, untuk memberi gambaran kondisi sosial agro ekonomi yang ada dalam wilayah studi. Metode pengumpulan data primer dan sekunder dilakukan dengan beberapa pola pendekatan yang terdiri atas: 
$\sqrt{ }$ Pengumpulan langsung dari instansi, Biro Pusat Statistik (BPS), kantor pemerintah daerah tingkat kecamatan, desa, serta instansi terkait lainnya.

$\sqrt{ }$ Penyebaran kuisioner yang memuat daftar pertanyaan untuk disebarkan pada masyarakat dalam wilayah studi. Daftar pertanyaan yang dibuat harus memuat semua aspek yang diperlukan, untuk menujang perencanaan. Pola penyebaran kuisioner harus diatur sedemikian rupa, sehingga semua kondisi sosio agro ekonomi wilayah studi dapat terwakili dengan baik.

$\sqrt{ }$ Pekerjaan Lapangan

- Mengadakan survei inventarisasi perkembangan sosial penduduk.

- Mengadakan survei inventarisasi keadaan agronomi.

- Mengadakan survei dan inventarisasi keadaan ekonomi masyarakat

- Mengadakan survei dan inventarisasi persepsi masyarakat tentang kegiatan pengaman pantai.

Pengkajian/penilaian kelayakan ekonomi terhadap rencana kegiatan pembangunan pengaman pantai tujuan untuk menilai apakah kegiatan tersebut layak untuk dikembangkan ditinjau dari sisi ekonomi dan bisnis. Pada dasarnya dalam mengkaji kelayakan ekonomi dan finansial perlu dilihat perbandingan nilai manfaat dan nilai biaya yang dikeluarkan. Dengan asumsi bahwa pengaman pantai ini adalah infrastruktur publik yang dibangun untuk pembangunan masyarakat pada khususnya, maka metode analisis finansial yang digunakan adalah analisis ekonomi. Pada analisis kelayakan ekonomi, besarnya investasi tidak dihitung berdasarkan harga nyata tetapi pada harga yang didalamnya mengandung subsidi Pemerintah yang umum disebut sebagai harga bayangan atau shadow price. Untuk perhitungan pendapatan, pada analisis kelayakan ekonomi, selain pendapatan langsung juga dihitung pendapatan tidak langsung berupa manfaat yang diterima oleh masyarakat akibat adanya pengaman pantai. Dalam analisis kelayakan ekonomi, manfaat tersebut diupayakan untuk dikonversikan pada suatu harga

\section{Analisis Nilai Bersih Sekarang (Analisis NPV)}

Nilai bersih sekarang adalah nilai sekarang (net present) dari selisih antara benefit dan biaya pada tingkat discount rate tertentu. Metode perhitungan NPV adalah :

$$
N P V=\Sigma(B t-C t) D F
$$


2. Analisis Net Benefit Cost Ratio (Analisis Net B/C) Analisis net $B / C$ adalah perbandingan antara jumlah NPV positif
dengan jumlah NPV negatif. Perhitungan net $B / C$ adalah:

$$
\text { Net } \mathrm{B} / \mathrm{C}=\frac{\Sigma N P V \text { positif }}{\Sigma N P V \text { negatif }}
$$

3. Analisis IRR

Analisis EIRR digunakan untuk mengetahui persentase keuntungan dari suatu pembangunan pada setiap tahun. Perhitungan EIRR adalah :

$$
\text { EIRR }=r_{y}=\frac{\text { NPVpositif }}{\text { NPVpositif }- \text { NPVnegatif }}\left(\left(i_{2}-i_{1}\right)\right.
$$

Keterangan :

$i_{1}$ : Tingkat bunga pada NPV positif, dan

$i_{2} \quad$ : Tingkat bunga pada NPV negatif

Suatu pembangunan dikatakan layak secara ekonomi apabila :

a. NPV adalah positif;

b. net $\mathrm{B} / \mathrm{C}$ ratio $>1$; dan

c. EIRR lebih besar dari tingkat bunga Bank yang berlaku.

\section{HASIL ANALISIS}

Berdasarkan hasil penelitian bahwa permasalahan gerusan yang terjadi di pantai Calang adalah abrasi, yakni penggerusan garis pantai akibat hantaman gelombang yang datang dari arah tegak lurus pantai. Hal ini dikarenakan posisi pantai Calang yang terbuka terhadap lautan lepas (Samudera Hindia).

Pengamanan pantai Calang dan Krueng Sabee selain dilakukan dengan pembangunan bangunan pantai, juga direncanakan perlindungan pantai buatan secara hayati. Perlindungan pantai secara hayati tidak lain merupakan green belt dengan penanaman jenis-jenis tanaman Memperhatikan mantantai dan merupakan tegakan yang relatif kokoh. masyarakat serta tanat bagi perlindungan pantai dan nilai ekonomis bag tanaman yang diunaman tersebut tidak asing bagi masyarakat setempat, 
ini diusulkan untuk ditanam sesuai dengan kondisi lahan yang ada. Untuk lahan-lahan yang kering diusulkan tanaman Kelapa, lahan yang tergenang diusulkan untuk tanaman mangrove. Hasil survey lapangan dari $18 \mathrm{~km}$, menunjukkan ada sepanjang 4,80 km yang layak untuk ditanami Kelapa dan 290 ha yang layak untuk ditanami Mangrove. Green Belt untuk lahan kering lebarnya 200 meter, sehingga yang diusulkan untuk ditanami Kelapa seluas 96 hektar. Sedangkan lahan genangan (di muara Krueng Sabee) semuanya diusulkan untuk ditanami Mangrove.

Sedangkan pengaman pantai buatan yang cocok untuk diterapkan pada lokasi kajian ini adalah bangunan breakwater. Bangunan ini berfungsi untuk menahan gelombang yang datang langsung dari arah laut. Tipe breakwater yang akan dibuat adalah tipe rubble mound (gundukan), yakni yang terdiri atas lapisan inti (core) dan lapisan pelindung (armor).

Pekerjaan konstruksi pengamanan pantai Calang dan Krueng Sabee merupakan kegiatan yang lebih diorientasikan untuk kepentingan masyarakat banyak, baik yang bersifat benefit tangible maupun benefit intangible. Pendekatan perhitungan manfaat dari pembangunan tersebut bersifat ekonomis jukan finansial.

\section{Biaya Pembangunan Pengaman Pantai}

Biaya pembangunan seperti sudah dijelaskan sebelumnya, meliputi biaya pembangunan fisik bangunan pelindung pantai dan biaya untuk tanaman pelindung pantai. Biaya ekonomis pembangunan ini dijelaskan berikut ini

a. Biaya Ekonomis Pembangunan Fisik Bangunan Pelindung Pantai

Rencana biaya pembangunan fisik bangunan pengaman pantai Calang dan Krueng Sabee untuk 4 lokasi secara ekonomis rinciannya dapat dilihat pada Tabel 1 .

\section{Tabel 1.}

Rencana Biaya Pembangunan Fisik Bangunan Pengaman Pantai Calang dan Krueng Sabee

\begin{tabular}{|l|l|r|}
\hline No. & \multicolumn{1}{|c|}{ Lokasi } & \multicolumn{1}{c|}{ Biaya (Rp.) } \\
\hline 01. & Kampung Panton Makmur & $1.492 .799 .215,45$ \\
\hline 02. & Daerah Calang (Lapangan bola hingga muara Kuala Meursee) & $2.418 .230 .562,85$ \\
\hline 03. & Ruas jalan antara Kr. Sabee dan Calang & $607.947 .564,89$ \\
\hline 04. & Muara Krueng Sabee Total & $321.503 .014,47$ \\
\hline \multicolumn{2}{|c|}{ Tor } & $4.840 .480 .357,66$ \\
\hline
\end{tabular}


b. Biaya Investasi Analisis Ekonomis Pengembangan Pelindung Pantai Secara Hayati

Pengembangan pelindung pantai secara hayati ada 2 kegiatan, yaitu: (a) penanaman tanaman kelapa; (b) penanaman tanaman mangrove. Rencana biaya ekonomis untuk 2 kegiatan ini dapat dilihat pada Tabel 2.

Tabel 2.

Rencana Biaya Pembangunan Fisik Bangunan Pengaman Pantai Calang dan Krueng Sabee

\begin{tabular}{|c|c|r|r|}
\hline \multirow{2}{*}{ No. } & \multirow{2}{*}{ Jenis Tanaman } & \multicolumn{2}{|c|}{ Biaya (Rp.) } \\
\cline { 3 - 4 } & & Per hektar & \multicolumn{1}{c|}{ Total } \\
\hline 01. & Kelapa & $2.556 .700,00$ & $245.443 .200,00$ \\
\hline 02. & Mangrove & $17.550 .000,00$ & $5.089 .500 .000,00$ \\
\hline \multicolumn{2}{|c|}{ Total } & $20.106 .700,00$ & $5.334 .943 .200,00$ \\
\hline
\end{tabular}

c. Total Rencana Biaya Analisis Ekonomis Pengamanan Pantai Calang dan Krueng Sabee

Gabungan antara rencana biaya bangunan pengamanan pantai dan rencana biaya pengembangan tanaman hayati untuk pengamanan pantai sebesar Rp. 10.175.423.557,66. Perincian biaya untuk analisis ekonomis dapat dilihat pada Lampiran 1.

\section{Manfaat Pembangunan Pengaman Pantai}

Manfaat pembangunan ini secara garis besar dapat dibagi 2 bagian, yaitu : (a) manfaat dari pengembangan tanaman kelapa dan mangrove; (b) manfaat terhadap kegiatan perekonomian di Kota Calang. Asumsi-asumsi dalam menghitung manfaat pembangunan pengamanan pantai Calang dan Krueng Sabee, melalui pendekatan-pendekatan :

a. Manfaat dari tanaman Kelapa

Tanaman kelapa akan mulai berproduksi pada tahun ke 5 sampai dengan tahun ke 25. Manfaat (penerimaan) merupakan perkalian dari hasil produksi dengan harga di pasar Kota Calang sebesar 750 rupiah per butir.

b. Manfaat dari Mangrove

2) Kayu Mangrove

Tanaman mangrove berdasarkan literatur dapat mulai ditebang pilih pada tahun ke 20 , produktivitas per tahun $0,0625 \mathrm{~m}^{3} / \mathrm{ha}$ dengan harga 75.000 rupiah per $\mathrm{m}^{3}$. 
2) Kepiting Bakau

Lima tahun setelah menanam mangrove, hutan tersebut mulai dapat dieksploitasi kepitingnya. Produktivitas maksimal penangkapan kepiting bakau per tahunnya 0,95 ton/ha dengan harga 20.000 rupiah $/ \mathrm{kg}$.

3) Udang

Lima tahun setelah menanam mangrove, hutan tersebut mulai dapat dieksploitasi udang. Produktivitas maksimal penangkapan udang per tahunnya 1,5 ton/ha dengan harga 15.000 rupiah $/ \mathrm{kg}$.

4) Ikan

Penangkapan ikan di hutan mangrove dapat dilakukan setelah lima tahun penanaman. Produktivitas maksimal penangkapan ikan per tahunnya 0,50 ton/ha dengan harga 5.000 rupiah $/ \mathrm{kg}$.

b. Manfaat dari Kegiatan Ekonomi Masyarakat Calang

1) Biaya Transportasi

Biaya transportasi antara Calang ke Banda Aceh sebelum tsunami sebesar 60.000 rupiah per orang, setelah tsunami harga naik menjadi 100.000 rupiah per orang. Kenaikan ini ditempuh dalam jarak $185 \mathrm{~km}$. Kegiatan pembangunan pengamanan pantai Calang dan Krueng Sabee dilakukan dalam radius $18 \mathrm{~km}$, sekitar 0,1 dari jarak Calang ke Banda Aceh. Andil pembangunan ini identik dengan proporsi jarak yang ditempuh, sehingga benefit dari pembangunan pengamanan pantai adalah $0,1 \times 40: 000$ rupiah per orang yaitu sebesar 4.000 rupiah/orang. Setiap hari, masyarakat Calang yang menggunakan transportasi ke Banda Aceh rata-rata 30 orang/hari.

2) Harga Beras

Harga beras sebelum tsunami sebesar 2.500 rupiah per $\mathrm{kg}$, setelah tsunami harga beras naik menjadi 4.500 rupiah per kg. Kegiatan pembangunan pengamanan pantai Calang dan Krueng Sabee. Andil pembangunan ini identik dengan perubahan harga beras sebesar $0,1 \times 2.000$ rupiah per kg. Setiap tahun masyarakat Calang mengkonsumsi beras adalah 8.901 orang $\times 164,90 \mathrm{~kg} / \mathrm{jiwa} / \mathrm{tahun}$ (kebutuhan beras per kapita). Laju pertumbuhan penduduk di Kecamatan Krueng Sabee selama 25 tahun diasumsikan sebesar 1,082 persen/tahun.

3) Harga Ikan

Harga ikan sebelum tsunami sebesar 5.000 rupiah per $\mathrm{kg}$, setelah tsunami harganya naik menjadi 10.000 rupiah per kg. Kegiatan 
pembangunan pengamanan pantai Calang dan Krueng Sabee. Andil pembangunan ini identik dengan perubahan harga ikan sebesar 5.000 rupiah per kg. Produksi ikan di Kecamatan Krueng Sabee adalah 1.061,20 ton per tahun. Harga yang digunakan dalam analisis adalah 2.000 rupiah per $\mathrm{kg}$, harga ini merupakan $40 \%$ dari marjin yang berlaku sekarang.

Berdasarkan asumsi-asumsi yang telah dikemukakan di atas, benefit ekonomis dari kegiatan ini dapat dilihat pada Lampiran 2.

Analisis Kelayakan Ekonomis

Studi kelayakan merupakan salah satu alat untuk membantu dalam menentukan kelayakan suatu pembangunan, dengan membuat perkiraan arus manfaat (benefit), arus biaya yang meliputi investasi, biaya operasional pembangunan dihitung dalam periode waktu tertentu yang disesuaikan dengan umur ekonomis pembangunan tersebut.

Kriteria studi kelayakan untuk menentukan kelayakan pembangunan ini meliputi NPV, Net B/C dan IRR. Pembangunan layak untuk dilaksanakan apabila dapat memenuhi kriteria-kriteria yang meliputi NPV $>0$, Net B/C $>1$ dan IRR $>$ Tingkat Bunga Bank yang berlaku. Analisis yang digunakan dalam kegiatan ini adalah analisis ekonomis.

Hasil perhitungan dari analisis ekonomis, pembangunan ini dalam jangka waktu 25 tahun pada tingkat bunga 24 persen diperkirakan memiliki NPV sebesar 1.018.582.359,72, Net B/C 1,131 dan IRR adalah 26,89 persen. Dengan memperhatikan hasil analisis ini (NPV, Net B/C dan IRR), pembangunan ini layak untuk dilaksanakan, karena dapat memberikan nilai tambah (value added). Perincian mengenai analisis kelayakan ekonomis kegiatan ini dapat dilihat pada Lampiran 3.

\section{KESIMPULAN}

Dari pembahasan diatas, maka dapat ditarik beberapa kesimpulan sebagai berikut :

1. Pengamanan pantai Calang dan Krueng Sabee selain dilakukan dengan pembangunan bangunan pantai, juga direncanakan perlindungan pantai buatan secara hayati. Perlindungan pantai secara hayati tidak lain merupakan green belt dengan penanaman jenis-jenis tanaman yang dapat tumbuh dipantai dan merupakan tegakan yang relatif kokoh. Tanaman yang diusulkan adalah Kelapa dan Mangrove. 
2. Pengaman pantai buatan yang cocok untuk diterapkan pada lokasi kajian ini adalah bangunan breakwater..

3. Hasil perhitungan dari analisis ckonomis, pembangunan ini dalam jangka waktu 25 tahun pada tingkat bunga 24 persen diperkirakan memiliki NPV sebesar 1.018.582.359,72, Net B/C 1,131 dan IRR adalah 26,89 persen.

\section{DAFTAR PUSTAKA}

Abdul Choliq, Rivai Wirasasmita dan Sumarna Hasan. 1999. Evaluasi Pembangunan (Suatu Pengantar) Edisi Revisi. Penerbit Pionir Jaya. Bandung.

Aceh Media Center. 2005. Tsunami, Karakteristik dan Pencegahannya. Yayasan Air Putih. http://www.airputih.or.id/. Sabtu, 8 Januari 2005.

Tim Peneliti. 2006. Rencana Pengelolaan Cagar Alam Teluk Bintuni Tahun 2006 - 2030. Balai Konservasi Sumber Daya Alam Papua II. Direktorat Jenderal Perlindungan Hutan dan Konservasi Alam. Departemen Kehutanan. Jakarta.

*) Sumarna Hasan adalah Staf Pengajar Fakultas Pertanian Universitas Winaya Mukti 